\title{
Comparison of relative abundance and diversity of coccinellids (Coleoptera: Coccinellidae) in blueberries (Vaccinium corymbosum L.), under two production systems in the La Araucanía Region, Chile
}

\author{
Marcela Vera, Alfonso Aguilera, and Ramón Rebolledo \\ Universidad de La Frontera, Facultad de Ciencias Agropecuarias y Forestales. \\ Campus Valentín Letelier, Montevideo s/n, Temuco, Chile.
}

\begin{abstract}
M. Vera, A. Aguilera, and R. Rebolledo. 2010. Comparative study of the relative abundance and diversity of coccinellids (Coleoptera: Coccinellidae) in blueberries (Vaccinium corymbosum L.) under two production systems in La Araucanía Region, Chile. Cien. Inv. Agr. 37(2):123-129. Coccinellids have been used, throughout the world, in biological control programs of agriculture pests. In Chile this family has been studied by various authors, which addresses issues such as biology, predatory activity and distribution in herbaceous species, shrubs and trees, but their situation in blueberries, where there is an abundance of species, is unknown Coccinellid beetles were counted visually on two blueberry orchards, under organic and conventional management. This study was conducted at the Maquehue Experiment Station, in the central valley of "La Araucanía Region" in southern Chile, from September 2007 through May 2008 and was divided into two periods: from September 2007 through February 2008 with visual counts only on the foliage of the plants, and from March through May 2008 counts were done on the foliage and on of the plant in the soil around the plants. The greatest number of species was recorded in the organic garden in both sampling periods, but species diversity was the same for both production systems. Specify results better.
\end{abstract}

Key words: Blueberries, coccinellids, Eriopis connexa, Eriopis eschscholtzii, Hyperaspis sphaeridioides.

\section{Introduction}

At world level, the number of coccinellid species in different environments, both tropical and template is estimated in six thousand (Gonzalez, 2006); they are used in many countries in programs of biological control of aphids, phytophagus acari, scales, whiteflies and fungi (Richard and Davies, 1984; De Liñán, 1998; García et al., 1994).

Received August 14, 2009. Accepted November 5, 2009. Corresponding author: ramonr@ufro.cl
In Chile, this family was composed in 1989 by 33 genus and 76 species (Elgueta and Arriagada, 1989). González (2006) mentions that there are represented five Coccinellidae subfamilies in the country: Coccidulinae, Coccinellinae, Exoplectrinae, Scymninae and Sticholotidinae. There is currently a record of 93 coccinellid species in Chile (González, 2008).

The species of the Coccinellinae and Scymninae subfamilies feed mainly from Aphididae, while Sticholotidinae and Exoplectrinae feed more frequently from coccids. There is not sufficient information on Chilean Coccidulinae, although there are aphidophagus and coccidophagus species (González, 2006). 
The ontogeny and ethology of this family has been studied in Chile by Rivera (1904), Montes (1970), Etchegaray (1982), Aguilera, (1995) and Aguilera et al. (2006a), who describe the Coccinellidae biology, postural habits, description and duration of larval stage, environmental conditions influencing de development and hibernation cycle of the species in adult state. There are also outstanding works by Zúñiga (1967, 1985), González (1969), Carrillo et al., (1974), Lamborot and Guerrero (1979), Zúñiga et al. (1986), Prado (1991), Aguilera and Pacheco (1995), Grez and Prado (2000), Grez and Villagrán (2000), Aguilera et al. (2006a, 2006b) who research aspects on the predatory activity of this family. Aguilera et al. (2005) and Rebolledo et al. (2007) refer specifically to the distribution of the species in the La Araucanía Region and the substrates they frequent. According to Rebolledo et al. (2007), coccinellids live on herbaceous plants, shrubs and trees, which are vegetal substrates where species of the Coccinellini tribe are abundant and with known diversity. Nevertheless, in fruit trees like blueberries (Vaccinium corymbosum L.), the relative abundance and diversity of these insects, as well as how these populations vary among different management systems of this fruit tree is unknown.

In regard to the aforementioned, this work had the objective to determine coccinellid species, their relative abundance and diversity associated to blueberries, in orchards under conventional management and organic in the La Araucanía Region, Chile.

\section{Materials and methods}

A sector under conventional management and another under organic management were chosen for the coccinellids sampling, both located in the Experimental Season Maquehue (38 $47^{\prime}$ South and $73^{\circ} 42^{\prime}$ West), of Universidad de La Frontera, $14 \mathrm{~km}$ from Temuco, commune of Freire, La Araucanía Region, 100 M.S.L.

The agroclimatic area to which the site under study belongs corresponds $t$ the agroecologi- cal unit called Central Valley, with an annual pluviometric fall of 1328 , with prevailing soils derived from recent volcanic ashes, also known as trumaos (Rouanet et al., 1988).

\section{Sector under conventional management}

The blueberries coordinates were $18 \mathrm{H} 0699878$; UTM 5698450, determined with a GPS mod. III Plus, Garmin.

The blueberries orchard has an approximate surface of 0.2 ha, with the cultivars Elliot, Bluecrop, Brigitta and O'Neill. The plants are arranged in lines, at a distance of $1 \mathrm{~m}$ over the line and $2 \mathrm{~m}$ between lines.

During the season and period of study, the products applied in this orchard: glyphosate $(750 \mathrm{cc} /$ ha, in July), paraquat (600 g/ha in September), and boscalid + pyraclostrobin (188 g $+96 \mathrm{~g} / \mathrm{ha}$, in October) (Dilman Boero. 2007. Agricultural engineer. Manager Experimental Field Maquehue. Personal communication).

\section{Sector under organic management}

The coordinates of the blueberries under organic management were 18H 0699658; UTM 5698270 , measured with GPS. There is currently an associated complex of cultivations in this sector, planted at a sufficient spatial closeness to lead to complementation, in order to improve the yields (Altieri, 2008).

In the site of sampling, the cultivations are arranged in a plot composed by nine ridges and intercultivations (-blueberries-green manurevegetables -potato -blueberries-green manurevegetables-potato-blueberries). In each ridge header there were aromatic plants (wormwood, Artemisia absinthium L., aliso, Alyssum sp. L., oregan, Origanum vulgare L., thyme, Thymus vulgaris L., and lemon balm, Melissa officinalis L.), to attract plague species. The blueberries in this sector covered a approximate surface of 0.6 ha, where $1 \mathrm{~L}$ of liquid foliar fertilizer, prepared in the same farm (compost/plant) Supermagro 
in September, every 15 days, in October, November and December, and piretro every 15 days, in January and February.

The samplings were made from September 2007 to May 2008. only the aerial part of the plant was sampled in both sectors, between September 2007 and February 2008, and the foliage and the soil around the plants were sampled from March to May 2008, because in that date the coccinellids prepare to hibernate and were habitually in the soil. The visual revision of the blueberries plants was carried out from 14 to $17 \mathrm{H}$, in different and consecutive days, for each sampling season, in a completely randomized sampling with 10 repetitions.

Additionally, some specimens were collected manually, which were taken to the Laboratory of Applied Entomology of the Faculty of Agropequarian and forest Sciences of Universidad de La Frontera for determination.

The specific richness (S), total abundance $(\mathrm{N})$ and relative abundance (AB\%) species diversity $(\mathrm{H})$, diversity in maximum conditions (H’max) and evenness of Pielou (J) were determined. The results were analyzed by the U Man-Whitney non parametric test, because they did not fulfil the requirements of normality and homocedasticity, using the software SPSS 11.0.

\section{Results and discussion}

The captures from September 2007 to May 2008 resulted in the presence of three coccinellid species, belonging to the Coccinellinae subfamilies: Eriopis connexa chilensis Hoffmann, Eriopis eschscholtzii Mulsant and Scymninae Hyperaspis sphaeridioides (Mulsant).

A total of 711 specimens of Eriopis connexa chilensis Hofmann (91\%), 62 de Eriopis eschscholtzii Mulsant (8\%) and 1 of Hyperaspis sphaeridioides (Mulsant) (1\%) (Figure 1) were found during the sampling season.

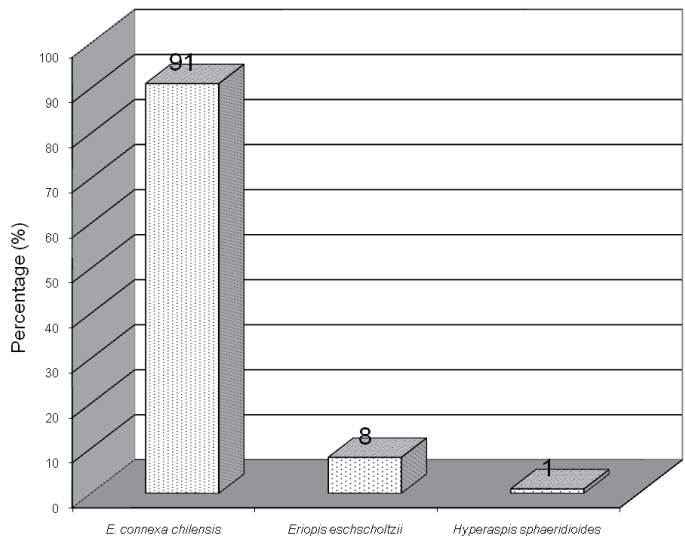

Figure 1. Total percentage of each coccinellid found on both orchards, from September 2007 through May 2008.

\section{Foliage samplings of the plants}

In the period September 2007 to February 2008, only Eriopis connexa chilensis was found with a total of 436 specimens (153 in the conventional orchard and 283 in the orchard under organic management) (Table 1), this is, with a relative abundance of $35.1 \%$ for the conventional orchard and $64.9 \%$ for the organic orchard (Figure 2).

Table 1. Population parameters of Coccinellidae in blueberry orchards under two production systems, during two periods.

\begin{tabular}{lcc}
\hline & \multicolumn{2}{c}{ Orchard } \\
\cline { 2 - 3 } Population indexes & Conventional & Organic \\
\hline September 2007 to February 2008 & 1 & 1 \\
$\mathrm{~S}$ (Species richness) & 153.0 & 283.0 \\
$\mathrm{~N}$ (Number of individuals) & 35.1 & 64.9 \\
$\mathrm{AB} \%$ (Relative abundante) & 0.0 & 0.0 \\
$\mathrm{H}^{\prime}$ (Diversity) & 0.0 & 0.0 \\
$\mathrm{H}^{\prime}$ máx. (Diversity in & 0.0 & 0.0 \\
maximum conditions) & & \\
$\mathrm{J}$ (Equity) & 3 & 3 \\
March to May 2008 & 164.0 & 181.0 \\
$\mathrm{~S}$ (Species richness) & 47.5 & 52.5 \\
$\mathrm{~N}$ (Number of individuals) & 0.53 & 0.61 \\
$\mathrm{AB} \%$ (Relative abundante) & & 1.09 \\
$\mathrm{H}^{\prime}$ (Diversity) & 1.09 & 0.56 \\
$\mathrm{H}^{\prime}$ máx (Diversity in \\
maximum conditions)
\end{tabular}




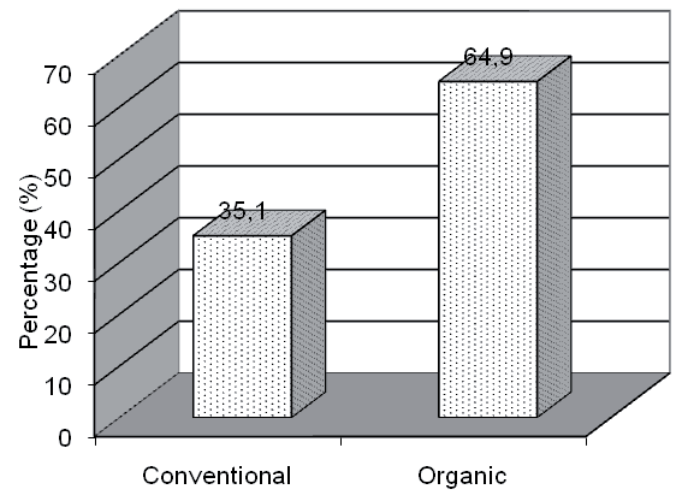

Figure 2. Relative abundance of coccinellids on blueberry orchards under to production systems, from September 2007 through February 2008.

For Eriopis connexa chilensis, the U Man-Whitney test resulted that for the period September de 2007 to February 2008, the populations from the conventional orchard and the organic orchard presented significant differences in their population means, with a $\mathrm{P}$ value fo 0.03 $(\leq 0.05)$. The specific richness for this period with only one taxon could occur because the blueberries cultivation in that period was not highly attractive for other coccinellid species, by the low presence of Aphididae observed. In addition, this coccinelid has good adaptability to different agroecosystems and has the capacity to multiply even in conditions of low feeding conditions (Bertolaccini et al., 1994), which might explain their abundance in the foliage of blueberry plants.

The different abundance of species between the orchards was significant, and could result because the organic orchard had a surface of 0.6 ha versus 0.2 ha of the conventional orchard, thus, the first orchard would have shown better conditions for E. connexa chilensis, for the higher amount of vegetation associated that acts as habitat for coccinellids, adding the fact that there was absence of herbicide management that might result toxic for the insects. According to Asteraki et al. (2004), Wackers (2004) and Rebolledo et al. (2007), the herbicides used to protect the weeds cultivations in fields under conventional management diminish the diversity of plants in the borders, with a loss in the number of shelters, alternative hosts and food resources for adult entomophagus. Additionally, the use of herbicides and fungicides may affect the coccinellid populations, because coccinellids are more sensitive than their preys to those products (Langhof et al., 2003; Symington, 2003).

The population parameters H (Diversity), H'max (Diversity in maximum conditions) and $\mathrm{J}$ (Evenness) were null in both orchards, which indicates that, as in the cultivation of organic blueberries as in the conventional blueberries, there were not any differences in the diversity of coccinellid species (Table1).

Foliage and soil samplings around the plants

In the samplings from March to May 2008, a total population of 345 specimens was obtained in both orchards, arranged in $47.5 \%$ in the conventional orchard and $52.5 \%$ in the organic orchard (Table 1).

The most numerous taxa in the samplings, in both the organic orchard and the conventional orchard was E. connexa chilensis, with a total of 275 specimens (80\%), followed by Eriopis eschscholtzii with 62 specimens (18\%) and then Hyperaspis sphaeridiodes with eight specimens (2\%) (Figure 3).

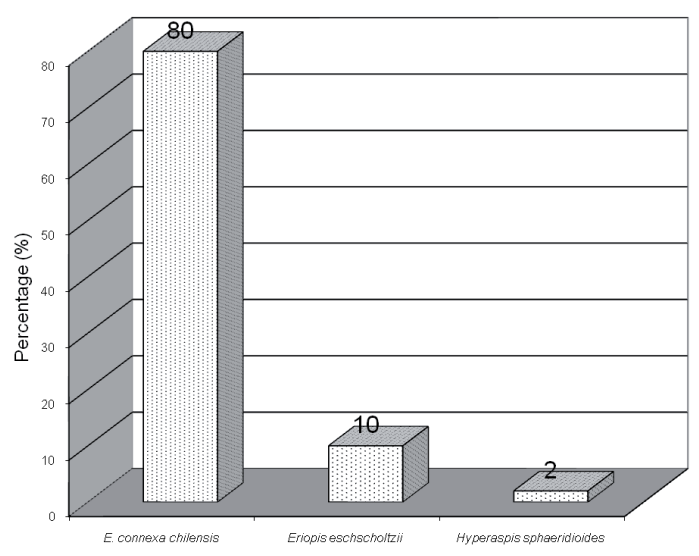

Figure 3. Percentages of species of coccinellids, considering both orchards, from March through May 2008

The U Man-Whitney test determined that both Eriopis species did not present significant differences in their mean populations between both 
orchards, with a $\mathrm{P}$ value of 0.67 , for $E$. connexa chilensis and 0.29 , for E. eschscholtzii $(\geq 0.05)$, therefore, the null hypothesis is accepted, which determines that both distributions are equivalent and without significant differences. $H y$ peraspis sphaeridioides could not be analyzed because only a few specimens were found.

The specific richness of three taxa in both orchards could be attributed because in both orchards there was a diversity of other close vegetal species, in addition to blueberries plants.

There was not any significant difference in the abundance of ladybugs in the orchards, which could occur because there were several plant species associated to blueberries in the organic orchard that might be more attractive for coccinellids; this occurs because there is a polycultural agroecosystem in the organic orchard, which according to Altieri and Nicholls (1999) produces an increased abundance of predators and parasitoids, result of a better availability of alternative preys, nectar sources and an appropriate microhabitat.
The results obtained indicate that the organic blueberries orchard presented a higher relative abundance of coccinellids than the conventional orchard, possibly because there was absence of a phytosanitarian management with herbicides and fungicides in the first orchard, which also presented a larger surface than the conventional orchard. Eriopis connexa chilensis presented the highest relative abundance, which could be due to the good adaptability to different agroecosystems and a high rate of reproduction. In addition, there were different blueberry cultivars in both the organic and conventional orchards, with only the O'Neill variety in common in both sectors, which could have influenced the results obtained.

\section{Acknowlegment}

DIDUFRO 120303 and D 108-0027 Projects of Research Department of Universidad de La Frontera (Temuco, Chile).

\section{Resumen}

M. Vera, A. Aguilera y R. Rebolledo. 2010. Comparación de la abundancia relativa y diversidad de coccinélidos (Coleoptera: Coccinellidae) en arándano (Vaccinium corymbosum L.) bajo dos modalidades de cultivo en la Región de La Araucanía, Chile. Cien. Inv. Agr. 37(2): 123-129. En todo el mundo, los coccinélidos se han utilizado en programas de control biológico de plagas agrícolas. En Chile esta familia ha sido estudiada por diversos autores, que tratan aspectos de biología, actividad depredadora y distribución de las especies en substratos herbáceos, arbustivos y arbóreos, pero en arándano se desconoce la diversidad y abundancia de especies de esta familia. Se hizo un estudio mediante recuentos visuales en la Estación Experimental Maquehue de la Universidad de La Frontera, en la región de La Araucanía de los coccinélidos presentes en dos huertos de arándano, uno bajo manejo orgánico y otro bajo manejo convencional, desde septiembre de 2007 a mayo de 2008, dividido en dos periodos, de septiembre de 2007 a febrero de 2008, con recuentos sólo en el follaje de las plantas, y de marzo a mayo de 2008 tanto en el follaje como en el suelo alrededor de ellas. La mayor cantidad de especies se contabilizó en el huerto orgánico, en ambos períodos de muestreo, y la diversidad fue la misma para ambos huertos.

Palabras clave: Arándano, coccinélidos, Eriopis connexa, Eriopis eschscholtzii, Hyperaspis sphaeridioides. 


\section{References}

Aguilera, A. 1995. Contribución al conocimiento de Coccinellina eryngii (Mulsant) (Coleoptera: Coccinellidae) en Chile. Acta Entomológica Chilena 19: 99-104.

Aguilera, A., and C. Pacheco. 1995. Determinación de depredadores del pulgón del avellano europeo Myzocallis coryli (Goeze) (Homoptera: Aphididae) en la Novena Región de Chile. Rev. Chilena Ent. (22): 11-19.

Aguilera, A., C. Klein, and R. Rebolledo, R. 2005. Distribución y abundancia relativa de Coccinellini (Coleoptera: Coccinellidae) en la Región de La Araucanía. Idesia (Arica, Chile) 23(1): 51-57. Aguilera, A., C. Klein, and R. Rebolledo, R. 2006a. Ciclo vital de Adalia angulifera Mulsant (Coleoptera: Coccinellidae) sobre el pulgón del avellano europeo Myzocallis coryli (Goeze) (Hemiptera: Aphididae). Agricultura Técnica (Chile) 66(3): 312-317.

Aguilera, A., R. Rebolledo,and C. Klein. 2006b. Coccinélidos (Coleoptera) depredadores de $\mathrm{My}$ zocallis coryli (Goeze), (Hemiptera:Aphididae) en La Araucanía, Chile. Idesia (Arica, Chile) 24(1): 13-16.

Altieri, M. 2008. Agroecología: principios y estrategias para el diseño de sistemas agrícolas sostenibles. Website accessed: 9 August, 2008. Available online at: http://agroeco.org

Altieri, M. and C. Nicholls. 1999. Biodiversity, ecosystem function and insect pest management in agricultural systems. In: Collins, W.W. and C.O. Qualset (eds.). Biodiversity in agroecosystems. CRC Press, Boca Raton, Florida pp. 69-84.

Asteraki, E., B. Hart, T. Ings, and W. Manley. 2004. Factors influencing the plants and invertebrate diversity of arable field margins. Agric. Ecosyst. Environ. 102: 219-231.

Bertolaccini, I., C. Salto,J. Imwinkelried, and P. Lubatti. 1994. Influencia de la alimentación larval sobre la fecundidad de Eriopis connexa Guerin (Coleoptera, Coccinellidae). Publ.Tec. INTA (Argentina) 25(2): 159-166.

Carrillo, R., M. Mellado, and A. Pinto. 1974. Los áfidos Sitobion avenae (Fab.) y Metopolophium dirhodum (Walk.), su influencia en el rendimiento, ubicación en la planta y sus enemigos naturales. Agro Sur (Valdivia, Chile) 2(2): 71-85.

De Liñan, C. 1998. Entomología Agroforestal. Ediciones Agrotécnicas, S.L. (España). $1253 \mathrm{p}$
Elgueta, D., and S. Arriagada. 1989. Estado actual de conocimiento de los coleópteros de Chile (Insecta: Coleoptera). Rev. Chilena Ent. 17: 5-60.

Etchegaray, J. 1982. Variación temporal de los estados de desarrollo de Eriopis connexa (Germar) (Coccinellidae) en Chile Central. Serie Medio Ambiente 6(1): 3-8.

García, F., J. Costa, and P. Ferragut. 1994. Plagas agrícolas. Agroplubli, S.L., Phytoma. España. $353 \mathrm{pp}$.

González, R. 1969. Biological control of citrus pests in Chile. Proc. First Int. Cit. Symp. 2: 839-847.

González, G. 2006. Coccinellidae de Chile. Website accessed: 3 April, 2006. Available online at: http://coccinelidae/introduccion-chinitas de Chile.htm

González, G. 2008. Lista y distribución de Coccinellidae en Chile. Boletín del Museo Nacional de Historia Natural (Arica, Chile) 57: 77-107.

Grez, A. and E. Prado. 2000. Effect of plant patch shape and surrounding vegetation on the dynamics of predatory Coccinellids and their prey, the cabbage aphid Brevicoryne brassicae. Environmental Entomology 29: 1244-1250.

Grez, A. and P. Villagrán. 2000. Effect of structural heterogeneity of a laboratory arena on the movement patterns of adult Eriopis connexa and Hippodamia variegata (Coleoptera: Coccinellidae). European Journal of Entomology 98: 563-566.

Lamborot, T., and M.A. Guerrero. 1979. Dinámica poblacional de los áfidos de cereales y sus enemigos naturales de la provincia de Santiago durante las temporadas 1976-1977. Investigación Agrícola (Chile) 5(1): 23-32.

Langhof, M., A. Gathmann, H. Poehling, and R. Meyhöfer. 2003. Impact of insecticide drift on aphids and their parasitoids: Residual toxicity, persistence and recolonisation. Agric. Ecosyst. \& Environ. 94: 265-274.

Montes, F. 1970. Biología y morfología de Eriopis connexa Germar, 1824 y de Adalia bipunctata (L., 1785) (Coleoptera). Publicaciones del Centro de Estudios Entomológicos (Chile) 10: 43-56.

Prado, E. 1991. Artrópodos y sus enemigos naturales asociados a plantas cultivadas en Chile. Boletín Técnico $\mathrm{N}^{\circ} 169$. Instituto de Investigaciones Agropecuarias, Santiago. $207 \mathrm{pp}$.

Rebolledo, R., A. Aguilera, R. Palma, and C. Klein. 2007. Coccinellini (Col., Coccinellidae) presentes en diferentes estratos vegetacionales en la IX Región de La Araucanía (Chile). Idesia (Arica, Chile) 25(1): 63-71. 
Richards, O. and R. Davies.1984. Tratado de entomologia IMMS. Ediciones Omega S.A., Barcelona, España. 901 pp.

Rivera, M. 1904. Desarrollo y costumbres de algunos insectos de Chile (coleópteros). Imp. Cervantes. Santiago, Chile. 55 pp.

Rouanet, J.; O. Romero, and R. Demannet. 1988. Áreas agroecológicas en la IX Región. Descripción. IPA Carillanca. Instituto de Investigaciones Agropecuarias. Temuco, Chile. 23 pp.

Symington, S.A. 2003. Lethal and sublethal effects of pesticides on the potato tuber moth, Phthorimaea operculella (Lepidoptera: Gelechiidae) and its parasitoid Orgilus lepidus Muesebeck (Hymenoptera: Braconidae). Crop Prot. 22: 513-519.

Wackers, F. 2004. Assesing suitability of flowering herbs as parasitoid food sources: Flower attrac- tiveness and nectar accessibility. Biol. Control 29: 307-314.

Zúñiga, E. 1967. Lista preliminar de áfidos que atacan cultivos en Chile, sus huéspedes y enemigos naturales. Agricultura Técnica (Chile) 27(4): 165-177.

Zúñiga, E. 1985. Ochenta años de control biológico en Chile. Revisión histórica y evaluación de los proyectos desarrollados (1902-1983). Agricultura Técnica (Chile) 45(3): 175-183.

Zúñiga, E.; J. Van Den Bosch, J. Drea, and F. Gruber. 1986. Control biológico de los áfidos (Hom.: Aphididae) de los cereales en Chile. II. Obtención, introducción y cuarentena de depredadores y parasitoides. Agricultura Técnica (Chile). 46(4): 479-487. 
